\title{
HUBUNGAN ANTARA EMPATI DENGAN PERILAKU PROSOSIAL PADA BYSTANDER UNTUK MENOLONG KORBAN BULLYING
}

\author{
Putra Lesmono ${ }^{1}$, Berta Esti Ari Prasetya ${ }^{2}$ \\ Universitas Kristen Satya Wacana ${ }^{1,2}$ \\ Email: putraliang95@gmail.com ${ }^{1}$ berta.prasetya@uksw.edu ${ }^{2}$
}

\begin{abstract}
Abstrak
Penelitian ini bertujuan untuk mengetahui ada atau tidaknya hubungan antara empati dengan perilaku prososial pada bystander untuk menolong korban bullying. Perilaku prososial yang dimaksudkan adalah untuk menguntungkan orang lain dengan salah satu faktornya adalah empati. Subjek penelitian ini adalah siswa-siswi SMP Kristen Satya Wacana Salatiga, kelas VIII dan IX, dengan kriteria subjek sebagai teman biasa dari korban bullying. Data diambil menggunakan metode kuantitatif dengan model purposive sampling. Berdasarkan hasil penelitian didapatkan hasil koefesien korelasi (r) =0,326 dengan nilai signifikansi 0,003; $\mathrm{p}$ $<0,05$ yang berarti terdapat hubungan positif antara empati dengan perilaku prososial pada bystander untuk menolong korban bullying di SMP Kristen Satya Wacana Salatiga, kelas VIII dan IX, dengan kriteria subjek sebagai teman biasa dari korban bullying.
\end{abstract}

Kata Kunci: Empati, Perilaku Prososial

\section{Abstract}

This study aims to determine whether or not there is a correlation between empathy and prosocial behavior for bystander to help victims of bullying. Prosocial behavior that is intended is to benefit others with one of the factors being empathy. The subjects of this study were Satya Wacana Salatiga Christian Junior High School students, grades VIII and IX, with the subject criteria being ordinary friends of bullying victims. Data was taken using quantitative methods with a purposive sampling model. Based on the research results obtained correlation coefficient $(r)=0.326$ with a significant value of $0.003 ; p<0.05$ which means there is a positive correlation between empathy and prosocial behavior bystander to help victims of bullying in Satya Wacana Christian Junior High School Salatiga, class VIII and IX, with the subject criteria as ordinary friends of victims of bullying.

Keywords: Empathy, Prosocial Behavior

PENDAHULUAN

$$
\text { Bullying secara luas dianggap }
$$

sebagai masalah serius di sekolah-sekolah di berbagai negara (Craiget; Smith, Monks, \& Coyne; dalam Djuwita \& Mangunsong, 2016), tidak terkecuali di Indonesia. Sejak tahun 2004 telah diperhatikan bahwa di sekolah-sekolah banyak terjadi bullying yang mengakibatkan beberapa siswa terluka parah dan bahkan dipukul sampai mati oleh seniornya. Menurut Djuwita dan Royanto; Riauskina, Djuwita, dan Soesetio (dalam Djuwita \& Mangunsong,
2016), kekerasan semacam ini merupakan masalah relatif yang baru dikenal sekolahsekolah di Indonesia dan masih diperdebatkan apakah bullying adalah masalah sebelumnya atau hanya fenomena baru yang terjadi di sekolah-sekolah di Indonesia. Studi menunjukkan bahwa tingkat tertinggi bullying diamati di sekolah menengah dibandingkan dengan tingkat sekolah lainnya.

Menurut data dari KPAI (Komisi Perlindungan Anak Indonesia) dari Januari hingga Mei 2018 mengenai kasus anak pelaku kekerasan dan bullying yang 
terjadi dalam bidang pendidikan yaitu sebanyak 161 kasus. Listyarti (2018) merinci, data kasus bidang pendidikan dikategorikan menjadi lima (5) bentuk, yaitu: anak korban tawuran sebanyak dua puluh tiga kasus atau 14,3\%, anak pelaku tawuran sebanyak tiga puluh satu kasus atau 19,3\%, anak korban kekerasan dan bullying sebanyak tiga puluh enam kasus atau $22,4 \%$, anak pelaku kekerasan dan bullying sebanyak empat puluh satu kasus atau $25,5 \%$, dan anak korban kebijakan (pungli, dikeluarkan dari sekolah, tidak boleh ikut ujian, dan putus sekolah) sebanyak tiga puluh kasus atau 18,7\% (nasional.tempo.co, 2018). Data Unicef tahun 2014 menyatakan delapan dari 10 anak mengalami bullying dan kasus bullying di Indonesia menempati urutan atau posisi keempat dalam kasus kekerasan anak (kpai.go.id, 2018).

Menurut Coloroso dan Barbara (2007) bullying adalah tindakan intimidasi yang dilakukan pihak yang lebih kuat terhadap pihak yang lebih lemah. Tindakan penindasan ini dapat diartikan sebagai penggunaan kekuasaan atau kekuatan untuk menyakiti seseorang atau kelompok sehingga korban merasa tertekan, trauma, dan tidak berdaya. Bentuknya bisa bersifat fisik seperti memukul, menampar dan memalak.
Bersifat verbal seperti memaki, menggosip, dan mengejek, serta psikologis seperti mengintimidasi, mengucilkan, mengabaikan, dan mendiskriminasi. Kekerasan dan perilaku negatif ini dapat terjadi di luar maupun di dalam sekolah.

Menurut Coloroso dan Barbara (2007) kebanyakan perilaku bullying berkembang dari beberapa faktor lingkungan yang kompleks. Tidak ada faktor tunggal menjadi penyebab munculnya bullying. Faktor-faktor penyebabnya antara lain: Faktor internal dan faktor eksternal. Faktor internal, anak ingin mendapatkan penghargaan diri dari orang lain dan belum memahami suatu perbuatan benar atau salah berdasarkan norma moral; dan faktor eksternal, dalam faktor eksternal ini terdapat lagi 3 faktor di dalamnya (faktor keluarga, faktor sekolah, dan faktor teman sebaya). Faktor keluarga: anak melihat orang tua atau saudara melakukan bullying sering akan mengembangkan perilaku bullying juga. Faktor sekolah: Pihak sekolah sering mengabaikan keberadaan bullying, sehingga anak akan mendapatkan penguatan terhadap perilaku mereka untuk melakukan intimidasi anak-anak yang lainnya. Faktor kelompok sebaya: Ketika anak-anak berinteraksi dalam sekolah dan 
dengan teman sekitar rumah kadang kala terdorong untuk melakukan bullying. Terkadang beberapa anak melakukan bullying pada anak yang lainnya dalam usaha untuk membuktikan bahwa mereka bisa masuk dalam kelompok tertentu, meskipun mereka sendiri merasa tidak nyaman dengan perilaku tersebut.

Menurut Rigby (dalam Halimah, Khumas, \& Zainuddin, 2015) perilaku bullying tidak bisa dibiarkan sebab menimbulkan dampak negatif pada siswa yang menjadi korban. Anak yang menjadi korban bullying akan merasa terganggu secara psikologis, seperti gugup, cemas, kurang tidur, takut, tidak mau melakukan apapun, membenci sekolah dan merasa stres setiap pagi ketika harus ke sekolah. Adapun secara fisik akan terlihat anak mengeluh sakit di bagian tertentu seperti di kepala, lutut, kaki, atau bahu. Bahkan bisa sampai demam dan muntah.

Menurut Coloroso dan Barbara (2007) pada dunia anak-anak, bullying biasanya terjadi karena adanya kerjasama yang bagus dari ketiga pihak, dengan istilah "tiga mata rantai penindasan". Pertama, bullying terjadi karena ada pihak yang menindas. Kedua, ada penonton yang diam atau mendukung, entah karena takut atau karena merasa satu kelompok. Ketiga, ada pihak yang dianggap lemah dan menganggap dirinya sebagai pihak yang lemah (takut bilang sama guru atau orangtua, takut melawan, atau malah memberi permakluman). Atas kerjasama ketiga pihak itu biasanya praktek bullying sangat sukses dilakukan oleh anak yang merasa punya power atau kekuatan. Pada penjelasan tersebut, sejumlah pakar tentang korban bullying, umumnya para korban itu memiliki ciri-ciri "ter", misalnya: terkecil, terbodoh, terpintar, tercantik, terkaya, dan seterusnya.

Menurut Hawkins, Pepler, dan Craig (2001) perilaku bullying bisa menjadi semakin meningkat karena kehadiran orang lain yang menyaksikan dan berada di lokasi saat peristiwa terjadi. Kehadiran orang lain saat terjadi peristiwa bullying dikenal dengan istilah bystander. Kehadiran bystander pada peristiwa bullying menjadi sebuah penguatan dan dukungan bagi pelaku. Penguatan pada perilaku bullying juga bersumber dari status sosial di kalangan sebaya sebab dapat meningkatkan popularitas pelakunya. Menurut Fonagy (dalam Halimah, Khumas, \& Zainuddin, 2015) bystander yang hadir pada peristiwa bullying berperan sebagai audiens yang membuat sebuah "teater" untuk menyaksikan pertunjukan pelaku. 
Menurut Myers (2002), bystander adalah orang yang menyaksikan keadaan darurat, tetapi tidak terlibat langsung. Pada buku Psikologi Sosial banyak menceritakan tentang pengamat yang mengamati situasi darurat seperti penusukan dan serangan seksual tanpa adanya bantuan. Sedangkan menurut Lipkins (dalam Basyirudin, 2010) bystander adalah orang-orang yang diterima kelompok dan sudah dilantik menjadi anggota. Pada beberapa kasus, mereka yang juga baru bergabung dalam kelompok bisa menjadi penonton, atau beberapa anggota senior bisa menjadi penonton dengan tipe yang beraneka ragam.

Berdasarkan pendapat sebelumnya yang telah dikatakan oleh Hawkins, Pepler, dan Craig (2001) mengenai kehadiran bystander saat terjadinya bullying, menjadi sebuah penguatan dan dukungan bagi pelaku sehingga perilaku bullying tersebut masih terus berlangsung. Hal itu juga berarti bahwa kehadiran bystander yang memiliki perilaku prososial untuk membantu orang yang menjadi korban bullying juga bisa membuat perilaku bullying tersebut dapat ditekan atau bahkan dihentikan.

Menurut Baron dan Byrne (2005) perilaku prososial merupakan suatu tindakan menolong yang menguntungkan orang lain tanpa harus menyediakan suatu keuntungan langsung pada orang yang melakukan tindakan tersebut, dan mungkin bahkan melibatkan suatu resiko bagi orang yang menolong. Sedangkan menurut Menurut Caprara, Steca, Zelli, dan Capanna (2005) perilaku menolong merupakan bentuk perilaku prososial berupa memberi bantuan kepada orang lain dengan meringankan aktivitas fisik orang tersebut.

Menurut Kau (2010), meskipun tindakan prososial dimaksudkan untuk memberikan keuntungan kepada orang lain, namun tindakan ini dapat muncul karena beberapa alasan. Misalnya, seorang individu mungkin membantu orang lain karena punya motif untuk mendapatkan keuntungan pribadi (mendapat hadiah), agar dapat diterima orang lain, atau karena memang dia benar-benar bersimpati, atau menyayangi seseorang. Fenomena menurunnya perilaku prososial pada remaja dapat dilihat pada rendahnya perilaku tolong menolong, berbagi, dan bekerjasama, antara remaja dengan remaja, orang lain, orang tua, maupun masyarakat. Perilaku prososial tidak semata-mata berdasarkan pada logika, pemahaman, atau penalaran, karena beberapa kondisi emosi menjadi penyebab 
dari munculnya perilaku prososial, di antaranya empati.

Menurut Staub (1978), ada beberapa faktor yang mempengaruhi individu dalam berperilaku prososial. Faktor-faktor yang mempengaruhi perilaku prososial adalah self-gain, personal values and norms, dan empathy. Empati merupakan faktor yang menentukan perilaku prososial remaja. Empati berkaitan secara positif dengan perilaku menolong. Ada juga bukti-bukti eksperimental bahwa empathic distress akan membangkitkan individu untuk menolong orang lain, dan observer yang mengalami empathic distress lebih tinggi akan memberikan pertolongan secara tepat kepada korban yang mengalami kesakitan. Sementara itu, jika mereka tidak melakukan suatu pertolongan maka observer empathic distress menjadi merasa bersalah dan mereka merasa lebih baik jika memberikan pertolongan (Hoffman, dalam Taufik, 2012).

Menurut Feshbach (dalam Kau, 2010) empati adalah kondisi emosi dimana seseorang merasakan apa yang dirasakan orang lain seperti dia mengalaminya sendiri, dan apa yang dirasakannya tersebut sesuai dengan perasaan dan kondisi orang yang bersangkutan. Meskipun empati merupakan respon yang bersifat emosi namun juga melibatkan ketrampilan kognitif seperti kemampuan untuk mengenali kondisi emosi orang lain dan kemampuan mengambil peran. Sedangkan menurut Davis (1980), empati merujuk pada kesadaran individu untuk dapat berpikir, merasakan, dan mengerti keadaan orang lain dilihat dari perspektif orang tersebut, sehingga individu tahu dan benar-benar dapat merasakan apa yang dirasakan dan dipikirkan oleh orang tersebut.

Menurut Eisenberg dan Paul (1987), empati berhubungan positif dengan berbagai perilaku prososial: membantu, sukarelawan, sumbangan, kerjasama, dan altruisme. Berdasarkan hasil penelitian yang telah dilakukan oleh Cialdini, Bauman, dan Kenrick (dalam Baron \& Byrne, 2005), menyatakan bahwa perilaku menolong dapat berperan sebagai perilaku self-help untuk mengurangi perasaan negatif pada diri sendiri (menciptakan afeksi positif). Hal ini didukung oleh riset yang dilakukan oleh Walker dan Christensen (dalam Rianggareni, 2015) yang menemukan bahwa empati dan regulasi diri berperan dalam perilaku prososial anak kepada teman-teman bahkan orang asing. Hal ini senada dengan hasil penelitian Thompson 
dan Gullone (2008) yang menyebutkan bahwa empati berkorelasi positif dan sangat signifikan dengan perilaku prososial. Akan tetapi, hasil penelitianpenelitian yang telah disebutkan di atas berbeda dengan hasil penelitian yang telah dilakukan oleh Rahman (2002), yang menyatakan bahwa perilaku prososial tidak dipengaruhi dan tidak berhubungan signifikan dengan kualitas empati. Hal ini terlihat dari hasil penelitian yang menyebutkan bahwa variabel empati berada pada kategori sedang, dan perilaku prososial berada dalam kategori rendah.

Pada penelitian ini, peneliti ingin mengetahui adanya hubungan yang positif dan signifikan antara empati dengan perilaku prososial pada bystander untuk menolong korban bullying. Hal ini dikarenakan hasil dari data Unicef pada tahun 2014 menunjukkan delapan dari 10 anak mengalami kasus bullying, sementara di Indonesia menempati peringkat keempat kasus kekerasan anak pada kasus bullying tersebut.

\section{METODE}

Penelitian ini menggunakan pendekatan kuantitatif, dengan metode penelitian deskriptif, sedangkan untuk jenis penelitian adalah jenis penelitian korelasional. Populasi dalam penelitian ini adalah siswa-siswi SMP Kristen Satya
Wacana Salatiga, kelas VIII dan IX. Sampel yang diambil sebanyak 70 siswa dan siswi dengan karakteristik subjek bystanders yang memiliki kriteria sebagai teman biasa dari korban bullying.

Teknik pengambilan sampel yang digunakan pada penelitian ini adalah menggunakan teknik purposive sampling atau teknik penentuan sampel dengan pertimbangan tertentu. Sedangkan untuk penarikan sampel jumlahnya harus representatif agar hasilnya dapat digeneralisasi.

Penelitian ini menggunakan metode kuantitatif dengan teknik pengumpulan data berupa skala psikologi, terdiri dari skala perilaku prososial yang berjumlah 15 aitem dan skala empati yang berjumlah 45 aitem. Penelitian ini menggunakan metode kuantitatif dengan model purposive sampling.

Peneliti melakukan uji tryout terpakai terhadap skala perilaku prososial ini dan setelah 4 aitem yang gugur dihilangkan dalam satu kali putaran uji diskriminasi aitem, didapati item valid yang tersisa sebanyak 11 aitem dengan skor reliabilitas 0,781. Maka dapat dikatakan bahwa skala perilaku prososial memiliki reliabilitas tinggi.

Peneliti juga melakukan uji tryout terpakai terhadap skala empati ini dan 
setelah 22 aitem yang gugur dihilangkan dalam satu kali putaran uji diskriminasi aitem, didapati item valid yang tersisa sebanyak 23 aitem dengan skor reliabilitas 0,851. Maka dapat dikatakan bahwa skala perilaku prososial memiliki reliabilitas tinggi.

\section{HASIL DAN PEMBAHASAN}

\section{Perilaku Prososial}

Tabel 1. Kategorisasi Skor Variabel

Perilaku Prososial

\begin{tabular}{lllll}
\hline Kategori & Interval & Frekuensi & Presentase & Mean \\
\hline Sangat rendah & $11 \leq x<19.25$ & 0 & $0 \%$ & \\
\hline Rendah & $19.25 \leq x<27.5$ & 2 & $2.86 \%$ & \\
\hline Tinggi & $27.5 \leq x<35.75$ & 45 & $64.29 \%$ & 34.19 \\
\hline Sangat tinggi & $35.75 \leq x<44$ & 23 & $32.85 \%$ & \\
\hline Jumlah & \multicolumn{5}{c}{70} & $100 \%$ & \\
\hline \multicolumn{5}{c}{$\mathrm{SD}=3,52 ; \mathrm{Max}=44 ; \mathrm{Min}=11$} \\
\hline
\end{tabular}

Pada table 1 kategori skor variabel perilaku prososial dari sejumlah 70 subjek menunjukkan tingkat penyebaran kategori dari sangat rendah hingga sangat tinggi. Dapat dilihat bahwa pada kategori "Rendah" didapat persentase sebesar 2,86\%, pada kategori "Tinggi" didapat persentase sebesar $64.29 \%$, dan pada kategori "Sangat Tinggi" didapat persentase $32.85 \%$. Dari tabel di atas juga dapat di lihat bahwa mean/rata-rata sebesar 34.19 yang berada pada kategori "Tinggi".

\section{Empati}

Table 2 Kategorisasi Skor Variabel

Empati

\begin{tabular}{lllll}
\hline Kategori & Interval & Frekuensi & Presentase & Mean \\
\hline Sangat rendah & $23 \leq \mathrm{x}<40.25$ & 0 & $0 \%$ & \\
\hline Rendah & $40.25 \leq \mathrm{x}<57.5$ & 9 & $12.86 \%$ & \\
\hline Tinggi & $57.5 \leq \mathrm{x}<74.75$ & 50 & $71.43 \%$ & 64.84 \\
\hline Sangat tinggi & $74.75 \leq \mathrm{x}<92$ & 11 & $15.71 \%$ & \\
\hline Jumlah & \multicolumn{5}{c}{70} & $100 \%$ & \\
\hline \multicolumn{5}{c}{$\mathrm{SD}=8,12 ; \operatorname{Max}=92 ; \operatorname{Min}=23$} \\
\hline
\end{tabular}

Pada table 2 kategori skor variabel empati dari sejumlah 70 subjek menunjukkan tingkat penyebaran kategori dari sangat rendah hingga sangat tinggi. Dapat dilihat bahwa pada kategori "Rendah" didapat persentase sebesar 12.86\%, pada kategori “Tinggi” didapat persentase sebesar $71.43 \%$, dan pada kategori "Sangat Tinggi" didapat persentase $15.71 \%$. Dari tabel di atas juga dapat di lihat bahwa mean/rata-rata sebesar 64.84 yang berada pada kategori "Tinggi".

\section{Uji Asumsi}

\section{Uji Normalitas}

Tabel 3. Normalitas Skala Empati dan Perilaku Prososial

One-Sample Kolmogorov-Smirnov Test

\begin{tabular}{|c|c|c|c|}
\hline & & Prososial & Empati \\
\hline $\mathrm{N}$ & & 70 & 70 \\
\hline \multirow[t]{3}{*}{ Normal Parameters $^{\mathrm{a}}$} & Mean & 34.19 & 64.84 \\
\hline & Std. & & \\
\hline & Deviation & 3.523 & 8.120 \\
\hline \multirow[t]{3}{*}{ Most Extreme Differences } & Absolute & .118 & .115 \\
\hline & Positive & .118 & .115 \\
\hline & Negative & -.083 & -.075 \\
\hline Kolmogorov-Smirnov Z & & .984 & .960 \\
\hline Asymp. Sig. (2-tailed) & & .288 & .315 \\
\hline
\end{tabular}

Uji normalitas menggunakan uji Kolmogrov-Smirnov yang menunjukan variabel perilaku prososial memiliki nilai K-S-Z sebesar 0.984 dengan signifikansi 
sebesar $0.00(\mathrm{p}>0.05)$. Pada variabel empati memiliki nilai K-S-Z sebesar 0.960 dengan signifikansi $0.00(\mathrm{p}>0.05)$. Dengan demikian dapat disimpulkan bahwa variabel perilaku prososial dan empati sama-sama berdistribusi normal.

\section{Uji Linearitas}

Tabel 4. Linearitas Skala Empati dengan Perilaku Prososial

\begin{tabular}{|c|c|c|c|c|c|c|c|}
\hline \multirow{5}{*}{$\begin{array}{l}\text { Prososial * } \\
\text { Empati }\end{array}$} & & ANO & $\begin{array}{l}\text { Table } \\
\text { Sum of } \\
\text { Squares }\end{array}$ & $\mathrm{df}$ & $\begin{array}{l}\text { Mean } \\
\text { Square }\end{array}$ & $\mathrm{F}$ & \multirow[t]{2}{*}{ Sig. } \\
\hline & \multicolumn{2}{|l|}{ Between } & & & & & \\
\hline & Groups & (Combined) & 472.119 & 30 & 15.737 & 1.596 & .085 \\
\hline & & Linearity & 90.895 & 1 & 90.895 & 9.220 & .004 \\
\hline & & $\begin{array}{l}\text { Deviation from } \\
\text { Linearity }\end{array}$ & 381.224 & 29 & 13.146 & 1.333 & .199 \\
\hline & \multicolumn{2}{|c|}{ Within Groups } & 384.467 & 39 & 9.858 & & \\
\hline & \multicolumn{2}{|l|}{ Total } & 856.586 & 69 & & & \\
\hline
\end{tabular}

Dari hasil uji linearitas tabel 3 diperoleh nilai $\mathrm{F}$ beda sebesar 1.333 dengan nilai sig. $0.199(p>0,05)$ yang menunjukan terdapat hubungan linear antara variabel empati dengan perilaku prososial.

\section{Uji Hipotesis}

\section{Uji Korelasi}

Berdasarkan uji asumsi yang telah dilakukan, diketahui bahwa data berdistribusi normal dan variabel-variabel penelitian linear. Sehingga uji korelasi yang digunakan dalam penelitian ini adalah korelasi Pearson.

Tabel 5. Korelasi antara Empati dengan Perilaku Prososial

\begin{tabular}{|c|c|c|c|}
\hline \multicolumn{4}{|c|}{ Correlation } \\
\hline & & Prososial & Empati \\
\hline \multirow{4}{*}{ Prososial } & Pearson & & \\
\hline & Correlation & 1 & $.326^{* *}$ \\
\hline & Sig. (1-tailed) & & .003 \\
\hline & $\mathrm{N}$ & 70 & 70 \\
\hline \multirow{4}{*}{ Empati } & Pearson & & \\
\hline & Correlation & $.326^{* * *}$ & 1 \\
\hline & Sig. (1-tailed) & .003 & \\
\hline & $\mathrm{N}$ & 70 & 70 \\
\hline
\end{tabular}

Dengan menggunakan uji korelasi Pearson diperoleh koefisien korelasi antara empati dengan perilaku prososial sebesar 0.326 dengan nilai signifikansi sebesar $0.003(\mathrm{p}<0.05)$ yang berarti ada hubungan yang positif dan signifikan antara empati dengan perilaku prososial. Makin tinggi empati maka semakin tinggi pula terciptanya perilaku prososial.

\section{PEMBAHASAN}

Pada penelitian ini terdapat hipotesis ada hubungan positif dan signifikan antara empati dengan perilaku prososial pada bystander untuk menolong korban bullying. Hasil penelitian yang diolah melalui uji korelasi Pearson menunjukan koefesien korelasi $(r)=0.326$ dengan nilai signifikansi $0.003 \quad(\mathrm{p}<0.05)$ yang berarti ada hubungan positif yang signifikan antara empati dengan perilaku prososial pada bystander untuk menolong korban bullying. Hal ini berarti semakin tinggi empati maka semakin tinggi juga perilaku prososial pada bystander untuk menolong korban bullying, begitu pula sebaliknya, semakin rendah perilaku prososial maka semakin rendah juga 
empati pada bystander untuk menolong korban bullying. Hasil ini sejalan dengan penelitian yang dilakukan oleh Permatasari (2008) yang menunjukkan bahwa ada hubungan yang positif dan signifikan antara empati dengan perilaku prososial.

Menurut Goleman (1995), empati memiliki andil besar dalam perilaku prososial, individu yang memiliki kemampuan berempati yang baik mampu mengambil perspektif orang lain dan mengungkapkan empati, sehingga mendorongnya untuk menolong. Menurut Azar (dalam Baron \& Byrne, 2005), empati yang dimiliki individu tidak terlepas dari keempat aspek empati yang dapat mendorong individu untuk melakukan perilaku prososial bagi orang lain. Keempat aspek tersebut menurut Davis (1980), yaitu: perspective taking, fantasy, empathic concern, dan personal distress memegang peranan penting dalam mengelola perasaan empati terhadap kesulitan orang lain.

Empati penting untuk dimiliki individu, Feshbach (dalam Kau, 2010) mengatakan bahwa dengan empati, seseorang dapat merasakan apa yang dirasakan orang lain seperti dia mengalaminya sendiri, dan apa yang dirasakannya tersebut sesuai dengan perasaan dan kondisi orang yang bersangkutan. Hal ini juga berlaku pada kasus bullying, dimana korban merasa terintimidasi oleh perilaku bullying yang dilakukan oleh pelaku. Tentunya jika individu memiliki empati dan melihat perilaku bullying tersebut, ia akan dapat merasakan hal yang sama seperti yang dirasakan oleh korban bullying tersebut, sehingga ia akan melakukan perilaku prososial untuk menolong korban bullying. Perilaku prososial itu diharapkan dapat mengurangi atau bahkan menghentikan perilaku bullying (Coloroso dan Barbara, 2007).

Selain itu sumbangan efektif dari empati terhadap perilaku prososial sebesar $10.63 \%$, sedangkan sisanya dipengaruhi oleh faktor lain sebesar $89.37 \%$. Dengan demikian empati bukan hal mutlak yang mempengaruhi perilaku prososial, melainkan terdapat faktor lain. Setidaknya ada beberapa faktor yang mempengaruhi perilaku prososial dari bystander untuk menolong korban bullying menurut Staub (1978), yakni: Self gain yang berarti harapan seseorang untuk memperoleh atau menghindari kehilangan sesuatu; Personal value and norms yang berarti adanya nilai-nilai dan norma-norma sosial pada individu selama mengalami sosialisasi dan sebagian nilai serta norma tersebut 
berkaitan dengan tindakan prososial; Empathy yang berarti kemampuan seseorang untuk ikut merasakan perasaan atau pengalaman orang lain.

Pada hasil penelitian ini didapati hasil bahwa siswa-siswi SMP Kristen Satya Wacana Salatiga dengan empati yang berkategori rendah sebanyak 9 orang (12.86\%), berkategori tinggi sebanyak 50 orang $(71.43 \%)$, dan berkategori sangat tinggi sebanyak 11 orang (15.71\%). Apabila disimpulkan, siswa-siswi SMP Kristen Satya Wacana Salatiga memiliki empati yang tinggi. Hal ini dibuktikan dari hasil perhitungan mean pada analisis deskriptif empati yang berkategori tinggi.

Pada variabel perilaku prososial didapati hasil bahwa sebanyak 2 orang $(2.86 \%)$ termasuk dalam kategori yang memiliki perilaku prososial rendah, sebanyak 45 orang $(64.29 \%)$ termasuk dalam kategori yang memiliki perilaku prososial tinggi, dan sebanyak 23 orang $(32.85 \%)$ termasuk dalam kategori yang memiliki perilaku prososial sangat tinggi. Apabila disimpulkan, siswa-siswi SMP Kristen Satya Wacana Salatiga memiliki empati yang tinggi. Hal ini dibuktikan dari hasil perhitungan mean pada analisis deskriptif empati yang berkategori tinggi.

\section{SIMPULAN}

Berdasarkan hasil penelitian diperoleh kesimpulan bahwa terdapat hubungan yang positif antara empati dengan perilaku prososial pada bystander untuk menolong korban bullying. Berdasarkan mean skor yang diperoleh, perilaku prososial yang dimiliki oleh siswa-siswi SMP Kristen Satya Wacana Salatiga termasuk dalam kategori tinggi. Sementara empati yang dimiliki oleh siswa-siswi SMP Kristen Satya Wacana Salatiga termasuk dalam kategori tinggi.

\section{DAFTAR PUSTAKA}

Baron, R. A., \& Byrne, D. (2005). Psikologi Sosial Jilid 2 Edisi Kesepuluh. Jakarta: Erlangga.

Basyirudin, F. (2010). Hubungan antara penalaran moral dengan perilaku bullying para santri madrasah aliyah pondok pesantren assa'adah serang banten. Skripsi Dipublikasi. Fakultas Psikologi: Universitas Islam Negeri (UIN) Syarif Hidayatullah.

Caprara, G. V., Steca, P., Zelli, A., \& Capanna, C. (2005). A new scale for measuring adults prosocialness. European Journal of Psychological Assessment, 21(2), 77-89. Doi: 10.1027/1015-5759.21.2.77.

Carlo, G., \& Randall, B. A. (2002). The development of a measure of prosocial behavior for late adolescents. Journal of Youth and Adolescence, 31(1), 31-44. Doi: 10.1023/A:1014033032440.

Coloroso, \& Barbara. (2007). Stop bullying (memutus rantai kekerasan anak dari prasekolah hingga smu). Jakarta: PT. Serambi Ilmu Semesta.

Davis, M. H. (1980). A multidimensional approach to individual differences in 
empathy. JSAS Catalog of Selected Documents in Psychology, 10, 6685.

Davis, M. H. (1983). Measuring individual differences in empathy: Evidence for a multidimensional approach. Journal of Personality and Social Psychology, 44, 113-126.

Djuwita, R., \& Mangunsong, F. M. (2016). Links between prosocial value and bystanders' helping behavior in bullying situation: The mediating role of collective efficacy and psychological well-being as moderator. The Asian Conference on Psychology and the Behavioral Sciences.

Eisenberg, N., \& Paul, A., M. (1987). The relation of empathy to prosocial and related behaviors. Psychological Bulletin, 101(1), 91-119.

Goleman, D. (1995). Emotional Intelligence. Jakarta: Gramedia Utama.

Halimah, A., Khumas, A., \& Zainuddin, K. (2015). Persepsi pada bystander terhadap intensitas bullying pada siswa smp. Jurnal Psikologi, 42, 129-140.

Hawkins, D. L., Pepler, D., \& Craig, W. M. (2001). Peer interventions in play-ground bullying. Social Development, 10, 512-527.

Kau, M. A. (2010). Empati dan perilaku prososial pada anak. Jurnal Inovasi, 7(3), 1-33.

Myers, D. G. (2002). Social Psychology. New York: McGraw Hill.

Permatasari, A. (2008). Hubungan antara empati dengan kecenderungan perilaku prososial pada perawat di rsu kardinah tegal. Surakarta: Universitas Muhammadiyah Surakarta.

Rianggareni, O. R. (2015). Hubungan antara empati dan perilaku prososial pada remaja di smpn 5 boyolali. Salatiga: Universitas Kristen Satya Wacana.

Sears, D. O., Freedman, J. L., \& Peplau, L. A. (1994). Psikologi Sosial Jilid 1. Jakarta: Erlangga.

Shapiro, L. (1997). Mengajarkan Emotional Intelligence pada Anak. Jakarta: Gramedia Pustaka Utama.

Staub, E. (1978). Positive Social Behavior and Morality. New York: Academic Press.

Taufik. (2012). Empati Pendekatan Psikologi Sosial. Jakarta: Rajawali Press.

Thompson, K., \& Gullone, E. (2008). Prosocial and antisosial behaviours in adolescents: An investigation into associations with attachment and empathy. Journal of the Interactions of People and Animals, 21, 123-137.

Referensi Lain :

Kpai.go.id. (2018). Kpai: Perundungan urutan keempat kasus kekerasan anak.

http://www.kpai.go.id/berita/kpaiperundungan-urutan-keempat-kasuskekerasan-anak. Diakses pada tanggal : 17 Maret 2019.

Nasional.tempo.co. (2018). Hari anak nasional, kpai catat kasus bullying paling banyak. https://nasional.tempo.co/read/1109 584/hari-anak-nasional-kpai-catatkasus-bullying-palingbanyak/full\&view $=o k$. Diakses pada tanggal : 14 Februari 2019.

Rahman, F. (2002). Kualitas empati dan intensi prososial sebagai dasar kepribadian konselor. http://staffnew.uny.ac.id/upload/132 300169/penelitian/KUALITAS+EM PATI+DAN+INTENSI+PROSOSI AL+MAHASISWA+BIMBINGAN +DAN+KONSELING.pdf. Diakses pada tanggal : 17 Maret 2019. 